\title{
Okul Öncesi Eğitim Kurumlarına Devam Eden 48-71 Aylık Çocukların Okul Algılarının Çizimler Aracılığıyla İncelenmesi
}

\section{Çocuk Gelişim Uzmanı İlknur Civek ${ }^{1 *}$ Dr. Öğr. Üyesi Özlem Çamlıbel Çakmak²}

Geliş tarihi: 08.05.2019

Kabul tarihi: 05.07.2019

\section{Atıf bilgisi:}

IBAD Sosyal Bilimler Dergisi

Sayı: 5 Sayfa: $70-88$

Yıl: 2019 Dönem: Güz

This article was checked by iThenticate. Similarity Index 17\%

1 Bolu AİBÜ İzzet Baysal Eğitim ve Araştırma Hastanesi, Türkiye, ilknurcivek@hotmail.com,

ORCID ID 0000-0002-7678-701X

2 Bolu Abant İzzet Baysal Üniversitesi, Türkiye ozlemcakmak@gmail.com, ORCID ID 0000-0002-5826-416X

\footnotetext{
* Sorumlu yazar
}

\section{Öz}

$\mathrm{Bu}$ araştırmanın amacı, okul öncesi eğitim kurumlarına devam eden 48-71 aylık çocukların okul algılarının çizdikleri resimler yoluyla incelenmesidir. Araştırmanın çalışma grubunu Bolu il merkezindeki 4 ilköğretim okulunun ana sınıfları ile 3 bağımsız anaokulundaki 48-71 aylık 117 çocuk olușturmaktadır. Araştırmanın amacı doğrultusunda nitel araştırma yöntemlerinden betimleyici durum çalışması deseni kullanılmıştır. Araștırma verileri "Bana bir okul resmi çiz" yönergesi verilerek resim çizdirme tekniği yoluyla toplanmış ve betimsel analiz yoluyla analiz edilmiştir. Araştırmada çocukların büyük çoğunluğunun resimlerinde okul binası çizdikleri ve okulu fiziksel özellikleri ile algıladıkları tespit edilmiştir. Okulun bazı çocukların resimlerinde sosyal ilişkilerin geliştirildiği sosyal bir ortam, bazı çocukların resinlerinde ise oyun ve hareket ihtiyaçlarını karşılayan bir yer olarak görüldüğü ortaya çıkmıştır. Araştırma sonucunda, çocukların okula ilişkin algılamalarında okul öncesi eğitim kurumlarının nitelik ve niceliğinin etkili olduğu sonucuna ulaşılmıştır.

Anahtar Kelimeler: Okul Öncesi Çocuk, Resim, Çizim, Okul Algısı. 


\section{Examining School Perceptions of 48-71-Month-Old Children Attending Pre-School Education Institutions Through Their Drawings}

\section{Child Development Specialist IIlknur Civek ${ }^{*}$ Asst. Prof. Özlem Çamlıbel Çakmak ${ }^{2}$}

First received: 08.05.2019 Accepted: 05.07.2019

\section{Citation:}

IBAD Journal of Social Sciences

Issue: 5 Pages: 70-88

Year: 2019 Session: Fall

This article was checked by iThenticate. Similarity Index 17\%

\footnotetext{
${ }^{1}$ Bolu AİBÜ İzzet Baysal Training and Research Hospital, Turkey, ilknurcivek@hotmail.com,

ORCID ID 0000-0002-7678-701X

2 Bolu Abant İzzet Baysal Üniversitesi, Turkey, ozlemcakmak@gmail.com, ORCID ID 0000-0002-5826-416X
}

\footnotetext{
* Corresponding Author
}

\begin{abstract}
The aim of this research was to examine the school perceptions according to the views of children aged 48-71 months and who attend pre-school educational institutions. 117 children who were 48-71 month old in kindergartens of 4 primary education schools and 3 independent infant schools in Bolu constitute the study group of the research. The descriptive case study pattern has been used for qualitative research methods. The data of the Research was collected by using the drawing technique and by giving the directive to the children to "Draw a picture of a school for me". The results were analyzed through descriptive analysis. After analysis, it has been determined that the majority of the children draw school building with physical characteristics. In some children's pictures, it has emerged that the school is seen as a social environment in which social relations are established and developed and in some children's pictures, the school is regarded as a place that meets the needs for play and movement. As a result of this research, it has been concluded that the quality and quantity of pre-school education institutions are influential in children's perception of the school.
\end{abstract}

Keywords: Preschool Child, Picture, Drawing, School Perception 


\section{GİRIŞ}

Okul adı verilen mekân ya da ortam bazılarına göre bir örgüt, bazılarına göre bir işletme, bazılarına göre bir aile, bazılarına göre de bir insan topluluğu olarak tanımlanmaktadır (Açıkalın, Şişman ve Turan, 2007). Okulların birey ve toplum açısından bakıldığında kültürel mirasın genç kuşaklara aktarılması, siyasi düzenin korunması, öğrencilerin ilgi ve yeteneklerini fark etmeleri ve bu doğrultuda eğitilmeleri konusunda üstlendiği birçok görevleri vardır (Sağlam, 2010). Ayrıca okullar, bireylerin gelişimlerine (zihinsel, bedensel, duygusal, sosyal vb.) katkıda bulunma, meslek edindirme, kendini gerçekleştirme gibi bireysel çıkarlarını gözeterek, onların okula karşı olumlu yönde güdülenmesini sağlarlar (Erden, 1998). Bu nedenle, okul, eğitim etkinliklerini ve ortamlarını bireyin ihtiyaçlarına uygun biçimde düzenlemelidir. Öyle ki çocuğun ailesinden sonra gelen ilk formal eğitim ortamı okul öncesi eğitim kurumlarıdır. Okul öncesi eğitim kurumları, okul öncesi çocuklarının eğitim ve bakımları ile ilgili kurumlardır (Demirel, 2010). Okul öncesi eğitim, Poyraz (2003, s. 21) tarafından şu şekilde tanımlanmıştır:

"Doğumdan ilkokulun başlangıcına kadar olan çocukluk yıllarını içine alan, bu yaş çocuklarının bireysel özelliklerini ve gelişimsel düzeylerine uygun zengin uyarıcı çevre imkânlarını sağlayan, onların tüm gelişimlerini toplumun kültürel değerleri ve özellikleri doğrultusunda en iyi bir biçimde yönlendiren bir eğitim sürecidir."

Okula başlamak, çocuklar için heyecan verici bir süreçtir. İnsan hayatının üçte birinin okul sınırları içinde geçtiği düşünüldüğünde, okul hem sosyal hem de eğitsel anlamda bireylerin yaşantısına etki eden önemli bir kurumdur (Yıldız, 2012). Çocuğun okula ilişkin algıları, kendi iç dünyasında yaşadığı durumlara ve içinde bulunduğu ortamın kendisine göre farklılık gösterebilir (Aksoy ve Baran, 2010). Bu yüzden hayatının başlangıcında ilk kez okulla tanışacak olan okul öncesi çocuklarının okulu nasıl algıladıkları önemlidir. Ayrıca Piaget, küçük çocukların dünyayı yetişkinlerin gördüğü gibi göremeyeceklerini belirtmiştir (Wood, 2003). Dolayısıyla okul ortamında çocuklara sunulan ortam ve etkinliklerin onlar açısından nasıl görüldüğü bilinmemektedir. 48-71 aylık çocukların okul algılarının resim yoluyla belirlenmesi bu konuda fikir verecektir.

Alan yazında okulun nasıl algılandığına ilişkin araştırmalar incelendiğinde, ilköğretim, lise, üniversite düzeyinde çok sayıda araştırmalar yapıldığı görülmektedir: (Akkaya, 2012; Aptekar, 1981; Aydoğdu, 2008; Bilgiç ve Sarı, 2010; Bülbül, 2014; Bülbül ve Toker Gökçe, 2015; Cerit, 2006; Çalık, 2008; Demir, 2007; Döş, 2011; Hofman, Hofman ve Guldemond, 2001; Inbar, 1996; Koçak, 2013; Levine, 2005; Mahlios ve Maxson, 1998; Nalçacı ve Bektaş, 2012; Özdemir ve Kalayc1, 2013; Saban, 2008; Taştan, 2013; Türkmen, 2014; Yıldız, 2012; Zieman ve Benson, 1981). Ancak okul öncesi eğitim düzeyinde çocukların okulu nasıl algıladığı ile ilgili sadece iki çalışmaya (Aksoy ve Baran, 2010; Geyik, Çalışkan ve Bay, 2019) rastlanmıştır. Okul öncesi eğitim kurumlarının, çocuğun okula ilişkin algısının oluşmasında ilk eğitim kurumları olduğu düşünüldüğünde okul öncesine giden 48-71 aylık çocukların okul algılarının araştırılması alan yazına önemli bir katkı sağlayacaktır.

Resimler çocukların iç dünyasını, olaylar hakkındaki duygu ve düşünüş biçimlerini, diğer çocuklar ve yetişkin insanlarla olan ilişkilerini yansıtan özgür ve yalın ifade araçlarıdır (Yavuzer 2013). Çocuklara resim çizdirmek güvenilir ve geçerli projektif tekniklerden biridir. Özellikle küçük çocuklar sınırlı sayıda kelime hazinesine sahiptirler (Ryan Wenger, 2001) ve görüşme esnasında kendilerini geri çekebilirler. Halbuki çocuklar resim yoluyla sözcüklere nazaran daha kolay ve eğlenceli bir şekilde kendilerini ifade edebilirler (Aral ve Metin, 2012; Skybo, Wenger ve Ying, 2007). Dolayısıyla, çocukların çizdiği resimler yoluyla, onların iç dünyasındaki duyguları, düşünceleri, görüşleri, büyüme süreci ve gelişimsel özellikleri hakkında daha fazla tanımlayıcı bilgiye ve ayrıntıya ulaşılabilmektedir (Wesson and Salmon, 2001; Yavuzer, 2013). Ayrıca çocuklara resimde neler çizdiklerini anlatmaları istendiğinde bir yetişkinin niyet okumasına gerek kalmadan özgürce ve doğru şekilde resimlerini anlatabilmektedirler. $\mathrm{Bu}$ bağlamda araştırmada okul öncesi eğitim kurumlarına devam eden 48-71 aylık çocukların okula ilişkin algılarının çizdikleri resimler aracılığıyla ortaya çıkarılması amaçlanmıştır. Araştırmanın alt amaçları şunlardır:

1- Okul öncesi eğitim kurumlarına devam eden 48-71 aylık çocukların resimlerinde çizdikleri mekânlara göre okul algıları nasıldır? 
a. Okul türüne göre nasıldır?

b. Cinsiyete göre nasıldır?

2- Okul öncesi eğitim kurumlarına devam eden 48-71 aylık çocukların resimlerinde kendini çizip çizmeme durumlarına göre okul algıları nasıldır?

a. Okul türüne göre nasildır?

b. Cinsiyete göre nasildır?

3- Okul öncesi eğitim kurumlarına devam eden 48-71 aylık çocukların resimlerinde kendisi dışında bir kimse ya da canlı/cansız varlıkları çizme durumlarına göre okul algıları nasıldır?

a. Okul türüne göre nasıldır?

b. Cinsiyete göre nasıldır?

4- Okul öncesi eğitim kurumlarına devam eden 48-71 aylık çocukların resimlerinde doğa öğelerini ve materyalleri çizme durumlarına göre okul algıları nasıldır?

a. Okul türüne göre nasıldır?

b. Cinsiyete göre nasıldır?

5- Okul öncesi eğitim kurumlarına devam eden 48-71 aylık çocukların resimlerinde ne yapıyor olduklarına göre okul algıları nasıldır?

a. Okul türüne göre nasıldır?

b. Cinsiyete göre nasıldır?

\section{YÖNTEM}

Okulöncesi eğitim kurumlarına devam eden 48-71 aylık çocukların okul algılarının nasıl olduğunu ortaya çıkarmak amacıyla yapılan bu araştırma nitel bir araştırmadır. Araştırmanın amacı doğrultusunda nitel araştırma yöntemlerinden betimleyici durum çalışması deseni kullanılmıştır. Merriam (2009) bu tür araştırmalarda bir kişi, bir program, bir grup ya da bir kurum ile ilgili sınırlandırılmış bir alanda derinlemesine betimlemeler ve incelemeler yapılmasının esas olduğunu belirtmiştir. Bu çalışmada da okul öncesi kurumlarına devam eden 48-71 aylık çocukların okul algılarını derinlemesine incelemek amacıyla resim çizdirme veri toplama tekniği kullanılmıştır.

\section{3. ÇALIŞMA GRUBU}

$\mathrm{Bu}$ araştırmada, amaçlı örnekleme yöntemlerinden maksimum çeşitlilik örnekleme yöntemi kullanılmıştır. Maksimum çeşitliliğe dayalı bir örneklem oluşturmada amaç, göreli olarak küçük bir örneklem oluşturmak ve bu örneklemde çalışılan probleme taraf olabilecek bireylerin çeşitliliğini maksimum derecede yansıtmaktır. Buradaki amaç, çeşitliliği sağlamak yoluyla evrene genelleme yapmak değil, çeşitlilik gösteren durumlar arasında herhangi ortak ya da paylaşılan olguların olup olmadığını bulmaya çalışmak ve bu çeşitliliğe göre problemin farklı boyutlarını ortaya koymaktır (Yıldırım ve Şimşek, 2013). Araştırmanın çalışma grubunu, Bolu İl Milli Eğitim Müdürlüğü’ne bağlı il merkezinde bulunan 4 ilköğretim okuluna bağlı anasınıfları ve 3 bağımsız anaokuluna devam eden 48-71 aylık çocuklar arasından çalışmaya gönüllü olan 117 çocuk oluşturmuştur. Çalışma grubundaki çocukların \%50,4'ü $(n=59)$ kız, \%49,6'sı $(n=58)$ erkek olup bu çocukların \%47,9'u (n= 56) anaokuluna, \%52,1'i $(\mathrm{n}=61)$ ana sinıfina gitmektedir.

\section{VERILERIN TOPLANMASI}

Araştırmanın verileri, araştırmaya katılan çocukları tanımak amacıyla ailelere dağıtılan "Çocuk Bilgi Formu" ile çocuklara resim çizdirilerek toplanmıştır. Her bir çocuğa A4 beyaz resim kâğıdı ile boya kalemleri sunulmuş ve “ Bana bir okul resmi çiz” yönergesi verilerek resim çizmesi istenmiştir. Çocukların istedikleri gibi rahatça resimlerini yapmaları ve kendilerini resimde ifade edebilmeleri için resimlerini bitirene kadar beklenileceği ve süre verileceği söylenmiştir. Resim tamamlandıktan sonra, çocuktan resimde neler çizdiğini anlatması istenerek araştırmacı tarafından çocuğun resminde anlattıkları yazılarak kaydedilmiştir. Resim çizme süresi, çocuğun hızına ve resme ilgisine göre bazı çocuklarla 10 dakika, bazı çocuklarla 20-30 dakika sürmüştür.

\section{VERILLERIN ANALİí}

Araştırma verileri, betimsel analiz tekniği kullanılarak analiz edilmiştir. Betimsel analiz yaklaşımına göre, elde edilen veriler daha önceden elde edilen temalara göre özetlenir ve yorumlanır. Veriler 
araştırma sorularının ortaya koyduğu temalara göre düzenlenebileceği gibi görüşme ve gözlem süreçlerinde kullanılan sorular ya da boyutlar dikkate alınarak da sunulabilir (Yıldırım ve Şimşek, 2013, s. 256). Verilerin analizinde, "Çocuk Bilgi Formu"ndan gelen cevaplar ile çocukların okulu anlatan resimleri ile ilgili bilgiler alan yazındaki resimlerle ilgili sorular ve boyutlar dikkate alınarak değerlendirmeye alınmıştır. Verilerin kolay anlaşılması için; örneğin: 1. Çocuk Ç1, Kız (K), Erkek (E) olmak üzere kodlanmıştır. Çocukların okulla ilgili yaptıkları resimleri, alan yazından alınan sorulara göre, temalar ve alt temalar halinde düzenlenerek frekans değerleri hesaplanmış ve tablolaştırılmıştır. Çocukların çizdikleri resimler; çizdikleri mekânlara, kendini çizip çizmeme durumlarına, kendisi dışında bir kimse ya da canlı/cansız varlık çizme durumlarına, materyale yer verme durumlarına ve ne yapıyor olduklarına göre incelenmiş, alan yazındaki araştırmalarla benzerlikleri ve farklılıkları karşılaştırılmış, yorumlanmış ve tartışılmıştır. Ayrıca resimlerde elde edilen temalar çocukların devam ettikleri okul türüne ve cinsiyetlerine göre de tablolaştırılarak yorumlanmış ve alan yazınında yapılmış çalışmalar ile karşılaştırmalar yapılarak tartışılmıştır. Araştırmanın geçerliğini sağlamak için çocukların okulla ilgili yaptıkları resimlere yer verilmiş, bunlardan yola çıkılarak bulgular arasındaki neden-sonuç ilişkileri açıklanmaya çalışılmıştır. Araştırmanın güvenirliğinin belirlenmesinde, resimlerin analizinde elde edilen veriler, araştırmacı ve bir uzman tarafından karşılaştırılarak temaların ve alt temaların oluşturulmasında fikir birliğine varılmıştır.

\section{BULGULAR}

Bu kısımda, okul öncesi kurumlarına devam eden 48-71 aylık çocuklara "Bana bir okul resmi çiz" yönergesi verildikten sonra çizdirilen okul resimlerinde çocukların çizdikleri mekânların durumları, çocukların kendini çizip çizmeme durumları, kendisi dışında bir kimse/canlı/cansız varlıkları çizme durumları, materyale yer verme durumları ve ne yapıyor oldukları ile tüm bu durumların çocukların devam ettikleri okul türüne ve cinsiyet açısından benzerlik gösterip göstermediği ile ilgili elde edilen bulgulara yer verilmiştir.

Tablo 6.1. Çocukların resimlerinde çizdikleri mekânların dağılımları

\begin{tabular}{ll}
\hline Mekân & $f$ \\
\hline Okul binası & 106 \\
Bahçe & 11 \\
Ev & 8 \\
Park & 5 \\
Sinıf & 4 \\
Kreş & 3 \\
Hayvan kulübesi & 3 \\
Futbol sahası & 3 \\
Havuz & 2 \\
Kulüp & 2 \\
Oyun evi & 2 \\
Spor aletleri binasi/salonu & 2 \\
Basket potası & 2 \\
Cami & 2 \\
Yol & 2 \\
Kulübe & 1 \\
Sirk çadırı & 1 \\
Dükkân & 1 \\
Okulun giriş holü & 1 \\
Balkon & 1 \\
\hline
\end{tabular}

Tablo 6.1. incelendiğinde, çocukların resimlerinde en çok okul binası ( $f: 106)$ çizdikleri görülmektedir. Bazı çocuklar resimlerinde okulun dış mekânlarından olan bahçeye $(f: 11)$, parka $(f: 5)$, futbol sahasına $(f: 3)$, basket potasına $(f: 2)$, hayvan kulübesine $(f: 3)$ yer verirken; bazı çocuklarda resimlerinde okulun iç mekânlarından sınıf $(f: 4)$ ve okulun giriş holü $(f: 1)$, spor salonuna $(f: 1)$ yer vermişlerdir. Bunun yanı sıra, bazı çocuklar resimlerinde okulun çevresinde bulunan ev (f: 8$)$, kreş $(f: 3)$, cami $(f: 2)$, yol $(f: 2)$, 
dükkân (f: 1) ile okul bahçesinde bulunmasını istedikleri havuz (f: 2), kulüp (f: 2), oyun evi, spor aletleri binası $(f: 1)$, kulübe $(f: 1)$, sirk çadırı $(f: 1)$ olmak üzere farklı mekânları da resimlemişlerdir. Aşağıda okul binası, kreş, bahçe ve yemek kulübünü çizen bir çocuğun resmi ve resmi ile ilgili görüş ifadesi örnek olarak verilmiştir (Resim 6.1.).

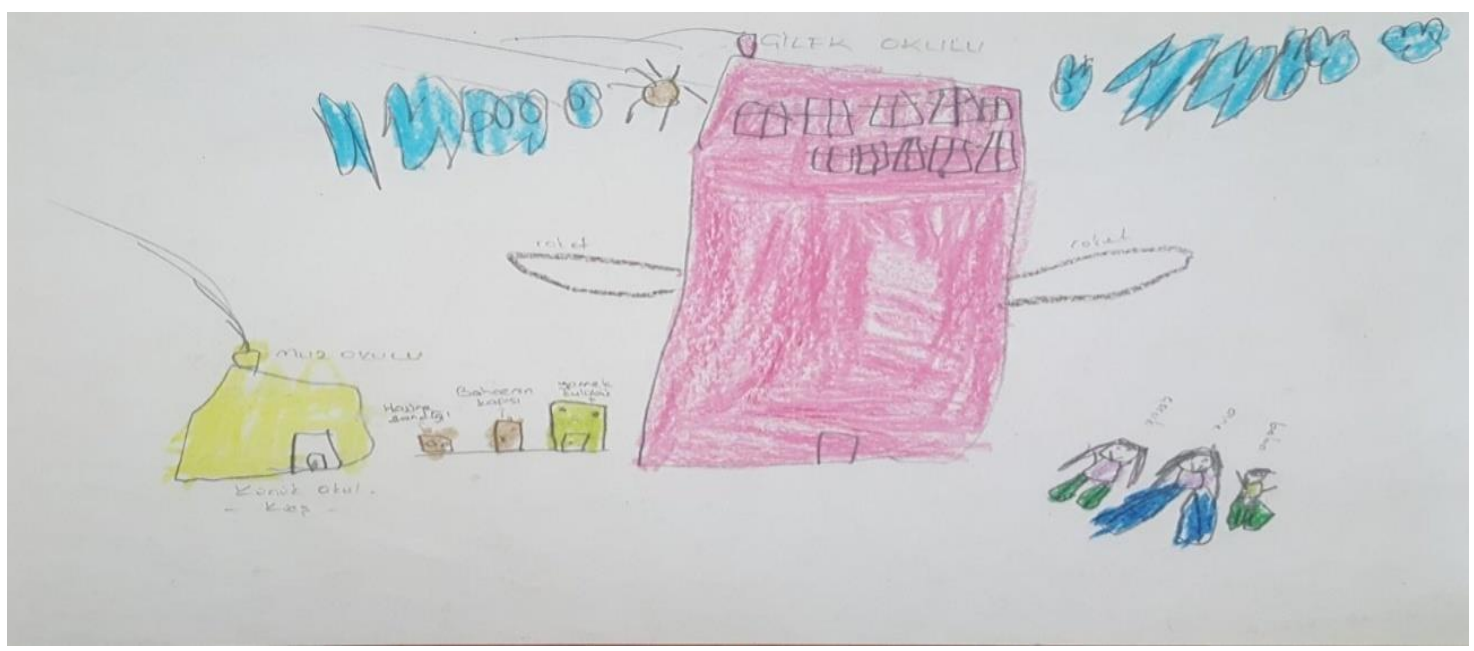

Resim 6.1. "Bir tane kız yaptım. Bu annesi. Bu babası. Bu yemek kulübü. Bu da bahçenin kapısı, bura hazine sandiğı var. Bura çilek okulu. Okulun uçabilmesi için roketler çizdim. Bu muz okulu, küçük okul, yani kreş. Keşke bu çizdiklerimi canlandırabilsek" (Ç15/K).

Tablo 6.2. Çocukların resimlerinde çizdikleri mekânların okul türüne göre dağılımları

\begin{tabular}{lll}
\hline Mekân & Ana sinıfi $(f)$ & Anaokulu $(f)$ \\
\hline Okul binası & 56 & 50 \\
Bahçe & 7 & 4 \\
Ev & 5 & 3 \\
Park & - & 5 \\
Sinıf & 1 & 3 \\
Kreş & 2 & 1 \\
Hayvan kulübesi & 1 & 2 \\
Futbol sahası & 2 & 1 \\
Havuz & - & 2 \\
Kulüp & 2 & - \\
Oyun evi & 2 & - \\
Spor aletleri binasi/salonu & 1 & 1 \\
Basket potası & 1 & 1 \\
Cami & 1 & 1 \\
Yol & 1 & 1 \\
Kulübe & 1 & - \\
Sirk çadırı & 1 & - \\
Dükkân & - & 1 \\
Okulun giriş holü & - & 1 \\
Balkon & - & 1 \\
\hline
\end{tabular}

Tablo 6.2. incelendiğinde, hem ana sınıfına giden çocukların $(f: 56)$ hem de anaokullarına giden çocukların (f: 50) en çok okul binası çizdikleri görülmektedir. Ana sınıfına giden çocukların hiçbiri resimlerinde park çizmemişlerdir, anaokuluna giden çocukların ise çok azı park $(f: 5)$ çizmişlerdir. Buna göre, 48-71 aylık çocukların resimlerinde çizdikleri mekânların okul türüne göre dağılımları genellikle benzer sonuçlar ifade etmiştir. 
Tablo 6.3. Çocukların resimlerinde çizdikleri mekânların cinsiyete göre dağılımları

\begin{tabular}{lll}
\hline Mekân & $\mathrm{K}(f)$ & $\mathrm{E}(f)$ \\
\hline Okul binasi & 53 & 53 \\
Bahçe & 3 & 8 \\
Ev & 3 & 5 \\
Park & 2 & 3 \\
Sinıf & 1 & 3 \\
Kreş & 2 & 1 \\
Hayvan kulübesi & 1 & 2 \\
Futbol sahası & 1 & 2 \\
Havuz & - & 2 \\
Kulüp & 2 & - \\
Oyun evi & 1 & 1 \\
Spor aletleri binasi/salonu & 2 & - \\
Basket potası & 1 & 1 \\
Cami & 1 & 1 \\
Yol & - & 2 \\
Kulübe & - & 2 \\
Sirk çadırı & 1 & - \\
Dükkân & 1 & - \\
Okulun giriş holü & - & 1 \\
Balkon & 1 & - \\
\hline
\end{tabular}

Tablo 6.3. incelendiğinde, hem kızlar hem de erkekler en çok okul binası $(f: 53)$ çizmişlerdir. Erkekler $(f$ : $8)$ kızlardan $(f: 3)$ biraz daha çok bahçe çizmişlerdir. Sadece erkekler havuz (f: 2$)$, yol $(f: 2)$, kulübe $(f$ : $2)$, ve okulun giriş holünü $(f: 1)$ çizmişken; sadece kızlar ise kulüp $(f: 2)$, spor aletleri binası/salonu $(f: 2)$, sirk çadırı $(f: 1)$, dükkan $(f: 1)$ ve balkon $(f: 1)$ çizmişlerdir. Buna göre, çocukların resimlerinde çizdikleri mekânlar cinsiyete göre genellikle benzer sonuçlar ifade etmiştir.

Tablo 6.4. Çocukların resimlerinde kendini çizip çizmeme durumlarına göre dağglımları

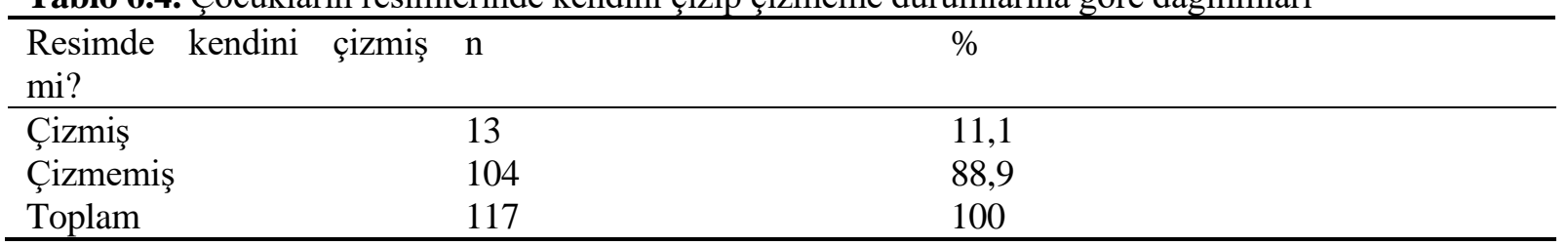

Tablo 6.4. incelendiğinde, "Bana bir okul resmi çiz" yönergesi verilen çocukların resimlerinde \%11,1'inin ( $\mathrm{n}=13)$ kendini çizmiş oldukları, \%88,9'unun $(\mathrm{n}=104)$ kendini çizmemiş oldukları görülmektedir. Aşağıda çocuklardan birinin resmi ve resmi ile ilgili görüş ifadesine yer verilmiştir (Resim 6.2.).

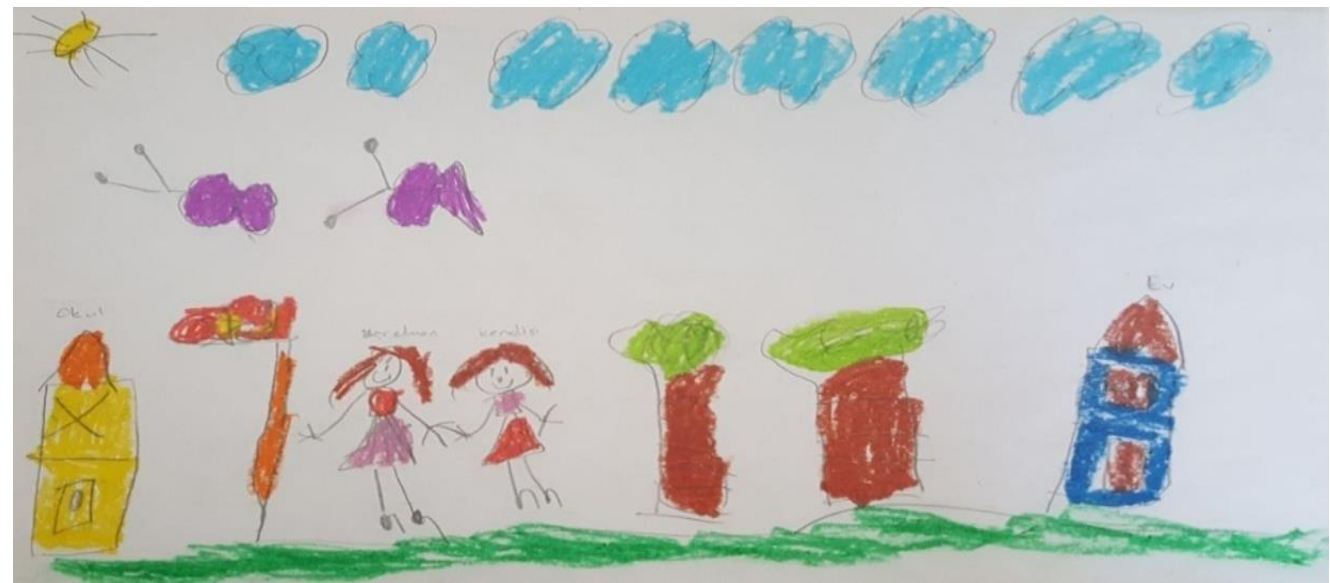

Resim 6.2. Ç11/K: “Öğretmen ve ben. El ele tutuşmuş okula gidiyoruz” (Ç11/K). 
Tablo 6.5. Çocukların resimlerinde kendini çizip çizmeme durumlarının okul türüne göre dağılımları

\begin{tabular}{|c|c|c|c|c|}
\hline & Ana sinıfi & & Anaokulu & \\
\hline $\begin{array}{l}\text { Resimde } \\
\text { kendini çizmiş } \\
\text { mi? }\end{array}$ & $\mathrm{n}$ & $\%$ & $\mathrm{n}$ & $\%$ \\
\hline Çizmiş & 5 & 8,2 & 8 & 14,3 \\
\hline Çizmemiş & 56 & 91,8 & 48 & 85,7 \\
\hline Toplam & 61 & 100 & 56 & 100 \\
\hline
\end{tabular}

Tablo 6.5. incelendiğinde, ana sınıfına giden çocukların \%8,2'sinin $(n=5)$ kendisini çizdiği, \%91,8'inin kendisini çizmediği; anaokullarına giden çocukların \% 14,3 ünün $(n=8)$ resminde kendini çizdiği, \%85,7'sinin kendisini çizmediği görülmektedir. Bu bulguya göre, çocukların resimlerinde kendilerini çizip çizmeme durumları okul türüne göre benzer sonuçlar ifade etmiştir.

Tablo 6.6. Çocukların resimlerinde kendini çizip çizmeme durumlarının cinsiyete göre dağılımları

\begin{tabular}{lllll}
\hline & $\mathrm{K}$ & & $\mathrm{E}$ & $\%$ \\
\hline $\begin{array}{l}\text { Resimde kendini } \\
\text { çizmiş mi? }\end{array}$ & $\mathrm{n}$ & $\%$ & $\mathrm{n}$ & 10,3 \\
\hline Çizmiş & 7 & 11,9 & 6 & 89,7 \\
Çizmemiş & 52 & 88,1 & 52 & 100 \\
Toplam & 59 & 100 & 58 & \\
\hline
\end{tabular}

Tablo 6.6. incelendiğinde, kızların \%11,9'unun ( $\mathrm{n}=7$ ) kendisini çizdiği, \%88,1'inin ( $\mathrm{n}=52)$ kendisini çizmediği; erkeklerin \%10,3'ünün $(n=6)$ resimlerinde kendisini çizdiği \%89,7'sinin $(n=52)$ kendisini çizmediği görülmektedir. Buna göre, çocukların resimlerinde kendilerini çizip çizmeme durumları cinsiyete göre benzer sonuçlar ifade etmiştir.

Tablo 6.7. Çocukların kendisi dışında bir kimse ya da canlı/cansız varlıkları çizme durumlarına göre dağılımları

\begin{tabular}{|c|c|}
\hline $\begin{array}{l}\text { Cocukların kendisi } \\
\text { kimseler ya da canlı/c }\end{array}$ & $\bar{f}$ \\
\hline Çocuklar & 27 \\
\hline Hayvan & 15 \\
\hline Anne & 6 \\
\hline Arkadaş & 4 \\
\hline Öğretmen & 4 \\
\hline İnsan & 3 \\
\hline Kardeş & 3 \\
\hline Baba & 3 \\
\hline Öğrenci & 2 \\
\hline Müdür & 1 \\
\hline Masal kahramanları & 1 \\
\hline Polis & 1 \\
\hline Hirsiz & 1 \\
\hline Araştırmacı & 1 \\
\hline
\end{tabular}

Tablo 6.7. incelendiğinde, çocukların çoğunluğunun resimlerinde sırasıyla en çok çocuklara (f: 27) ve hayvanlara $(f: 15)$ yer verdiği görülmektedir. Aşağıda okul ortamı ve okul ortamında bulunan kimselere yönelik bir örnek verilmiştir (Resim 6.3.). 


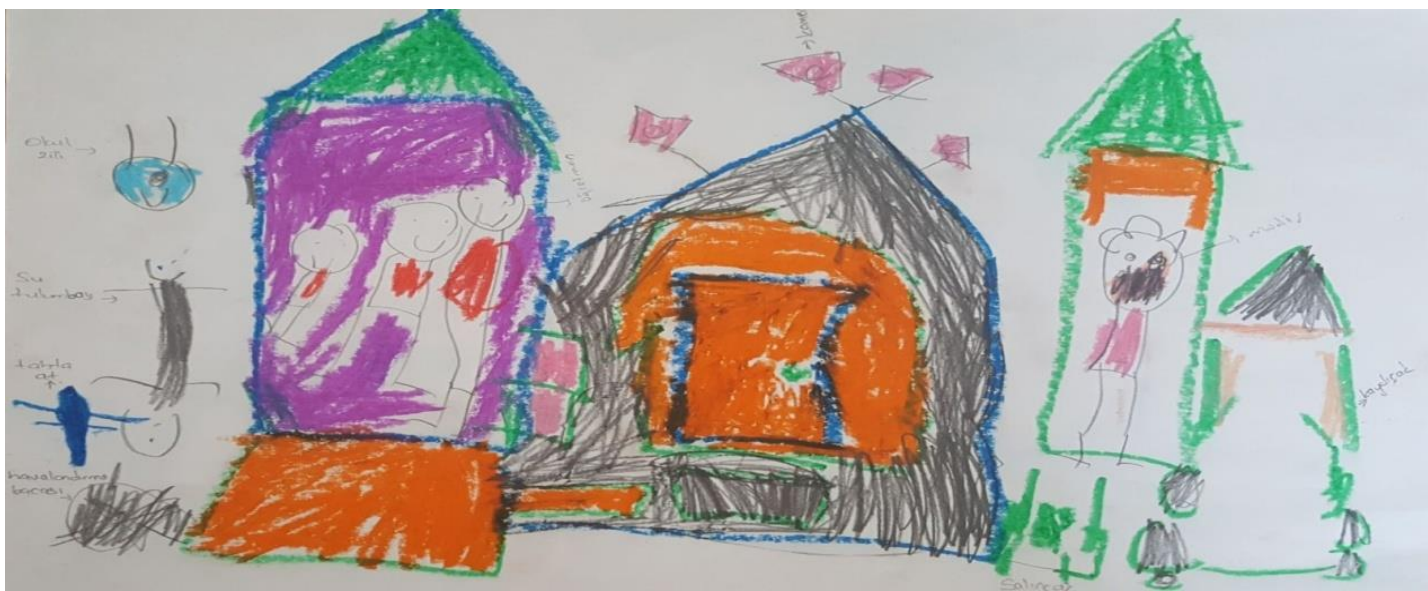

Resim 6.3. "Şaşmış bir müdür. Öğretmen ve öğrenciler. Kaydırak, salıncak, okul, okulun çevresi, su tulumbası, tahta at, havlandırma bacası, okulun çatısında kameralar” (Ç101/K)

Tablo 6.8. Çocukların kendisi dışında bir kimse ya da canlı/cansız varlıkları çizme durumlarının okul türüne göre dağglımları

\begin{tabular}{lll}
\hline $\begin{array}{l}\text { Çocukların kendisi dışında } \\
\text { çizdikleri kimseler ya da } \\
\text { canlı/cansız varlıklar }\end{array}$ & Ana sınıfi $(f)$ & Anaokulu $(f)$ \\
\hline Çocuklar & & \\
Hayvan & 19 & 8 \\
Anne & 8 & 7 \\
Arkadaş & 3 & 3 \\
Öğretmen & 2 & 2 \\
İnsan & 2 & 2 \\
Kardeş & 2 & - \\
Baba & 2 & 1 \\
Öğrenci & 1 & 2 \\
Müdür & - & 2 \\
Masal kahramanları & - & 1 \\
Polis & 1 & - \\
Hırsız & - & 1 \\
Araştırmacı & - & 1 \\
\hline
\end{tabular}

Tablo 6.8. incelendiğinde, hem ana sınıfina giden çocuklar hem de anaokuluna giden çocuklar en çok çocukları çizmişlerdir. Ancak ana sınıfina giden çocukların resimlerinde $(f: 19)$ anaokuluna giden çocukların resimlerine $(f: 8)$ göre daha çok çocukları çizdikleri görülmektedir. Her iki okul türüne devam eden çocukların benzer şekilde hayvan, anne, arkadaş, öğretmen, kardeş ve baba çizmişlerdir. Sadece ana sınıfına giden çocuklar insan, masal kahramanı ve araştırmacıyı çizmiş; sadece anaokullarına giden çocuklar ise öğrenci, müdür, polis ve hırsız çizmişlerdir. Buna göre, okul türü açısından çocukların resimlerinde kendisi dışında bir kimse ya da canlı/cansız varlıkları çizip çizmeme durumları genel olarak benzer sonuçlar ifade etmiş̧iir.

Tablo 6.9. Çocukların kendisi dışında bir kimse ya da canlı/cansız varlıkları çizme durumlarının cinsiyete göre dağılımları

\begin{tabular}{lllll}
\hline Çocukların kendisi dışında çizdikleri kimseler ya da canlı/cansız & $\begin{array}{l}\mathrm{K} \\
\text { varlıklar }\end{array}$ & $\mathrm{E}(f)$ \\
\hline Çocuklar & & 18 & 9 \\
Hayvan & & 11 & 4 \\
Anne & & 4 & 2 \\
Arkadaş & & 2 & 2 \\
Öğretmen & & 3 & 1 \\
Insan & & 1 & 1 \\
\hline
\end{tabular}




\begin{tabular}{lcc}
\hline Kardeş & 2 & 1 \\
Baba & 1 & 2 \\
Öğrenci & 1 & 1 \\
Müdür & - & 1 \\
Masal kahramanları & - & 1 \\
Polis & - & 1 \\
Hirsız & - & 1 \\
Araştırmacı & 1 & - \\
\hline
\end{tabular}

Tablo 6.9. incelendiğinde, kızlar resimlerinde erkeklerden göre daha çok çocuklar (f: 18) ve hayvan ( $f$ : $11)$, anne (f: 4), öğretmen ( $f: 3)$ resmi çizmişlerdir. Kızlardan sadece bir çocuk resminde araştırmay1 çizmişken; sadece erkekler resimlerinde, müdür, masal kahramanları, polis ve hırsız çizmişlerdir. Buna göre; kızlar resimlerinde daha çok bir kimse ya da canlı/cansız varlıklar çizdiğinden, çocukların resimlerinde kendisi dışında bir kimse ya da canlı/cansız varlıkları çizip çizmeme durumları cinsiyete göre farklı sonuçlar ifade etmiştir.

Tablo 6.10. Çocukların resimlerinde doğa öğelerini ve materyalleri çizme durumlarına göre dağılımları

\begin{tabular}{ll}
\hline Ana temalar & $f$ \\
\hline Doğa öğeleri & 197 \\
& \\
$\begin{array}{l}\text { Okul ve çevresine ait } \\
\text { materyaller }\end{array}$ &
\end{tabular}

Alt temalar gökyüzü, doğa olayları, yıldız, toprak, meyve, dağ, taş, kuş yuvası, kardan adam, tohum

materyaller

Pencere, kapı, çatı, oyuncaklar, baca, eşyalar, kaydırak, salıncak, bayrak, okul merdiveni, şekiller/semboller, çeşme, taşıtlar, bahçe kapısı, okulun demirleri, oturma yeri (bank), yangın merdiveni, tahterevalli, tırmanma merdiveni, havuz, kamera, trambolin, tahta at, spor aleti, sek sek çizgisi, okul zili, uçak bileti, posta kutusu, süt kutusu, beton, dükkân, evin parçası, annenin küpeleri

Tablo 6.10. incelendiğinde, çocukların resimlerinde en çok okul ve çevresine ait materyallere ( $f: 382)$ yer verdikleri, doğa öğelerine (f: 197) daha az yer verdikleri görülmektedir. Aşağıda çocukların resimlerinde doğa öğeleri ve materyallere yer verme durumları ile ilgili birer örnek verilmiştir (Resim 6.4.; Resim 6.5.)

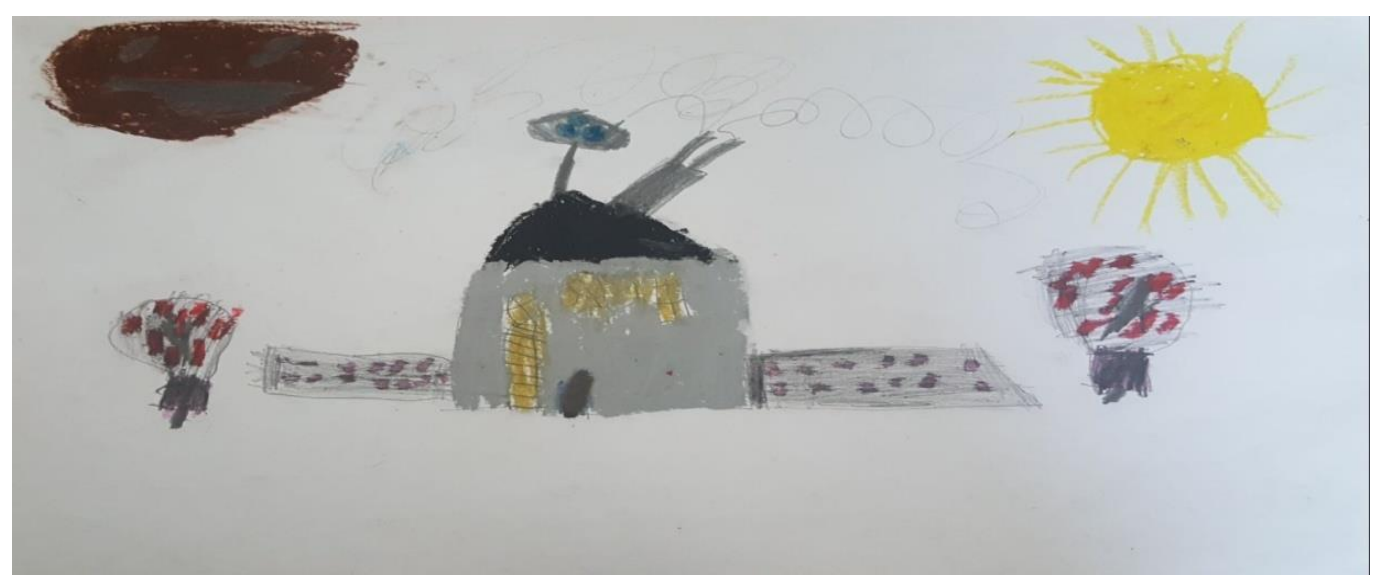

Resim 6.4. "Okul. Bu yangından kaçma yeri. Bacadan duman çıkıyor. Kuşlar yuva yapmış. Gözü ve ă̆zl olan bir dăg yaptım, komik olsun.

Okulun bahçesine tohum ekilmiş. Bahçede ağaçlar var. Bir de güneş" (Ç50/E). 


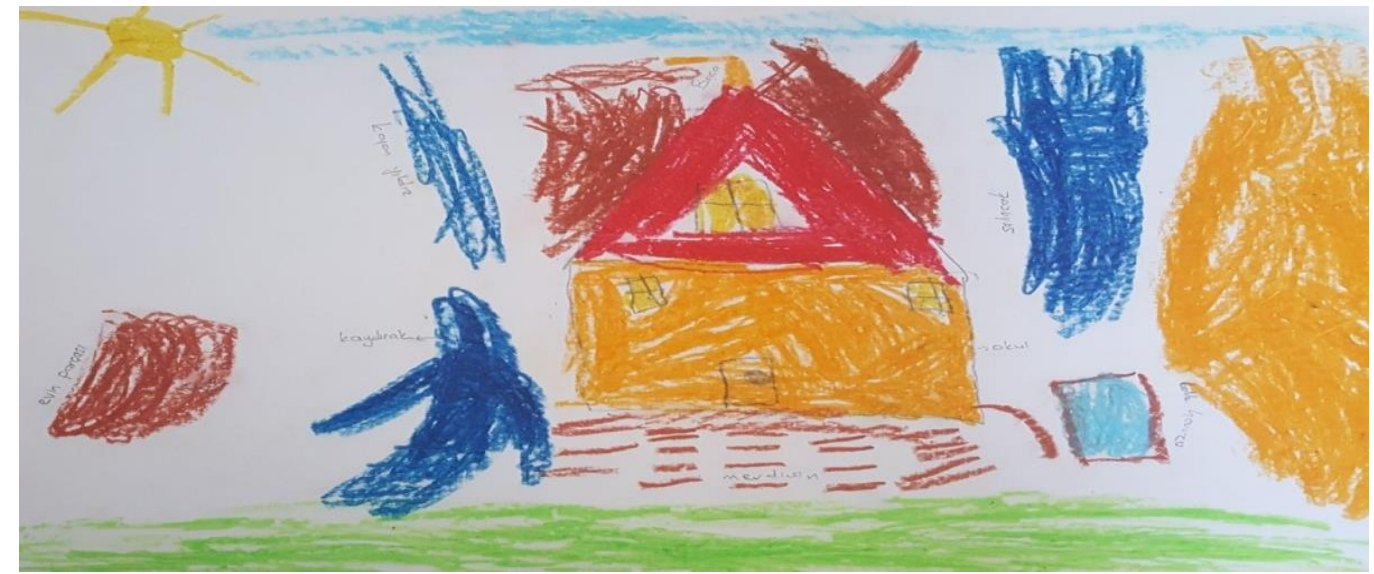

Resim 6.5. "Okul, okulun merdiveni. Kayan yıldız, güneş, bulutlar. Salıncak, kaydirak, evin parçası, balık havuzu, çimenler" (Ç80/E).

Tablo 6.11. Çocukların resimlerinde doğa öğeleri ve materyalleri çizme durumlarının okul türüne göre dağılımları

\begin{tabular}{|c|c|c|}
\hline Ana temalar & Ana sinifi $(f)$ & Anaokulu $(f)$ \\
\hline $\begin{array}{l}\text { Doğa öğeleri: } \\
\text { Güneş, çimen, bulut, çiçek, } \\
\text { ağaç, gökyüzü, doğa } \\
\text { olayları, yıldı, toprak, } \\
\text { meyve, dağ, taş, kuş yuvası, } \\
\text { kardan adam, tohum }\end{array}$ & 108 & 89 \\
\hline $\begin{array}{l}\text { Okul ve çevresine ait diğer } \\
\text { materyaller: } \\
\text { Pencere, kapı, çatı, } \\
\text { oyuncaklar, baca, eşyalar, } \\
\text { kaydırak, salıncak, bayrak, } \\
\text { okul merdiveni, } \\
\text { şekiller/semboller vb. }\end{array}$ & 194 & 187 \\
\hline
\end{tabular}

Tablo 6.11. incelendiğinde, hem ana sinıfina giden çocuklar hem de anaokuluna giden çocuklar resimlerinde en çok okul ve çevresine ait materyalleri, en az doğa öğelerini çizmişlerdir. Ayrıca ana sınıfına giden çocukların anaokuluna giden çocuklardan farklı olarak biraz daha çok okul ve çevresine ait materyallere ve doğa öğelerine yer verdikleri görülmektedir. Buna göre, çocukların resimlerinde doğa öğelerine ve materyallere yer verme durumları okul türüne göre benzer sonuçlar ifade etmiştir.

Tablo 6.12. Çocukların resimlerinde doğa öğelerini ve materyalleri çizme durumlarının cinsiyete göre dağılımları

\begin{tabular}{|c|c|c|}
\hline & $\mathrm{K}(f)$ & $\mathrm{E}(f)$ \\
\hline $\begin{array}{l}\text { Doğa öğeleri: } \\
\text { Güneş, çimen, bulut, çiçek, } \\
\text { ağaç, gökyüzü, doğa } \\
\text { olayları, y1ldı, toprak, } \\
\text { meyve, dağ, taş, vb. }\end{array}$ & 130 & 67 \\
\hline $\begin{array}{l}\text { Okul ve çevresine ait diğer } \\
\text { materyaller: } \\
\text { Pencere, kapı, çatı, } \\
\text { oyuncaklar, baca, eşyalar, } \\
\text { kaydırak, salıncak, bayrak, } \\
\text { okul merdiveni, } \\
\text { şekiller/semboller vb. vb. }\end{array}$ & 201 & 179 \\
\hline
\end{tabular}


Tablo 6.12. incelendiğinde, kızların resimlerinde okula ve çevresine ait materyalleri (201) doğa öğelerinden (130) daha çok çizdikleri görülmektedir. Benzer şekilde erkeklerin de okul ve çevresine ait materyalleri (179) doğa öğelerinden (67) daha çok çizdikleri görülmektedir. Kızlar erkeklere göre daha çok doğa öğelerini ve okul ile çevresine ait materyalleri çizmişlerdir. Buna göre, çocukların resimlerinde doğa öğelerine ve materyallere yer verme durumları cinsiyete göre farklı sonuçlar ifade etmiştir.

Tablo 6.13. Çocukların resimlerinde ne yapıyor olduklarına göre dağılımları

Çocukların resimlerinde ne yapıyor oldukları

Çocuklar dışarıda oyun oynuyor

19

(Oyun oynuyorlar, kaydıraktan kayıyor, top oynuyor, çocuklar yarışma yapıyorlar, kızlar ip atlıyorlar, kız arkadaşları tahterevalliye binmiş, arkadaşı basket oynuyor)

Okula gidiyorlar/geliyorlar 10

Çocuklar okulun içinde oyun oynuyorlar $\quad 6$

Kız spor yapiyor

Teneffüs bitmiş öğrenciler okula girmiş

Okula kim geliyormuş diye camdan bakıyor

Camide ailece namaz kılıyorlar

1

1

1

Tablo 6.13. incelendiğinde, çocukların resimlerinde en çok çocukları dışarıda oyun oynarken çizmiş oldukları görülmektedir. Aşağıda çocukların resimlerinde ne yapıyor olduklarına dair örneklere yer verilmiştir (Resim 6.6., Resim6.7.).

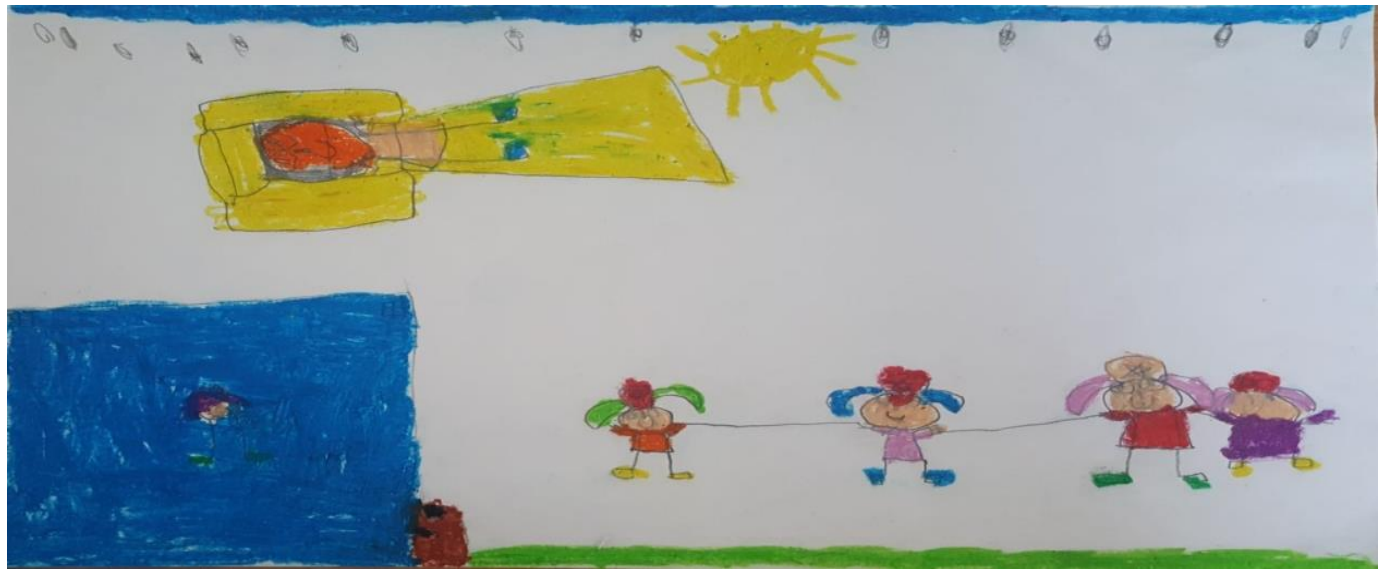

Resim 6.6. "Bunlar kizlar, ip atllyorlar. Burada kız kaydırağa biniyor" (Ç17/K).

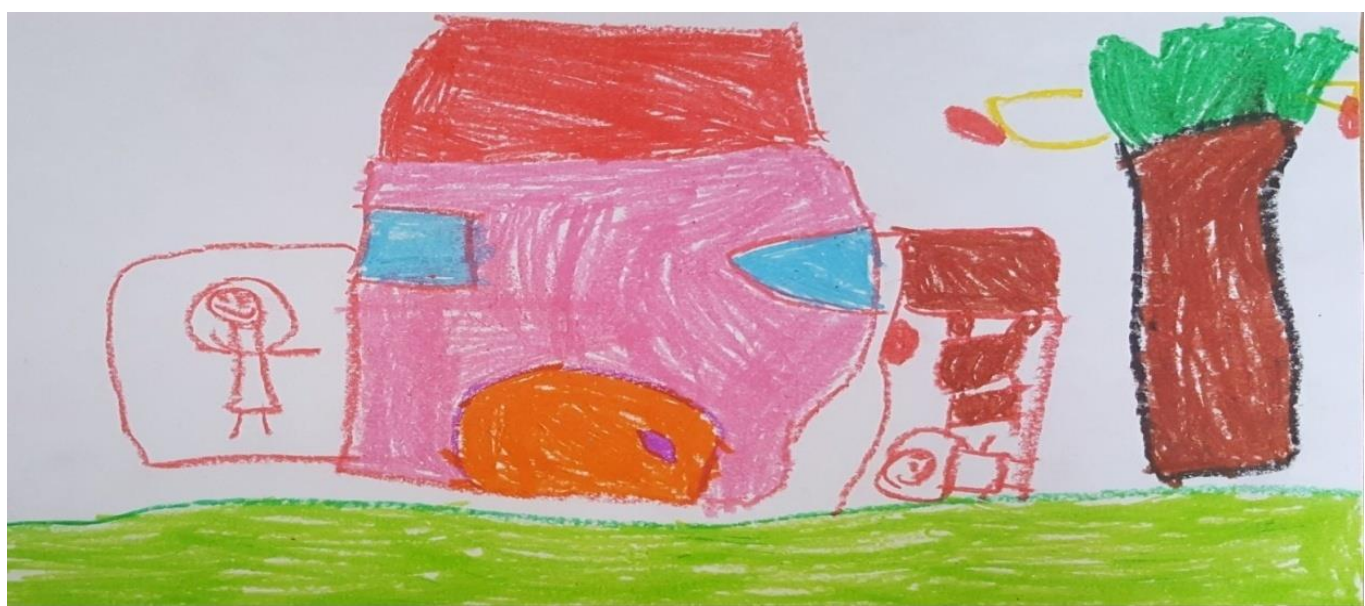

Resim 6.7. "Okul. Burası spor salonu, klz spor yapıyor. Burası sinıf, klz oyun oynuyor”(Ç88/K). 
Tablo 6.14. Çocukların resimlerinde ne yapıyor olduklarının okul türüne göre dağılımları

\begin{tabular}{|c|c|c|}
\hline $\begin{array}{l}\text { Çocukların resimlerinde ne } \\
\text { yapıyor oldukları }\end{array}$ & Ana sinıfi $(f)$ & Anaokulu $(f)$ \\
\hline $\begin{array}{l}\text { Çocuklar dişarıda oyun } \\
\text { oynuyorlar }\end{array}$ & 15 & 4 \\
\hline Okula gidiyorlar/geliyorlar & 6 & 4 \\
\hline $\begin{array}{l}\text { Çocuklar okulun içinde } \\
\text { oyuncaklarla oynuyorlar }\end{array}$ & - & 6 \\
\hline K1z spor yapiyor & - & 1 \\
\hline $\begin{array}{l}\text { Teneffüs bitmiş öğrenciler } \\
\text { okula girmiş }\end{array}$ & 1 & - \\
\hline $\begin{array}{l}\text { Okula kim geliyormuş diye } \\
\text { camdan bakıyor }\end{array}$ & - & 1 \\
\hline $\begin{array}{l}\text { Camide ailece namaz } \\
\text { k1liyorlar }\end{array}$ & - & 1 \\
\hline
\end{tabular}

Tablo 6.14. incelendiğinde ana sınıfına giden çocuklar resimlerinde, sırasıyla en çok çocukları dışarıda oyun oynarken (f:15), okula gidip gelirken (f: 6), teneffüs bitmiş öğrenciler içeri girmiş (f: 1) çizmiş, okulun içinde oyun oynarken çizmemişlerdir. Sadece anaokullarına giden çocuklar, çocukları okulun içinde oyuncaklarla oyun oynarken (6) çizmişlerdir. Buna göre, çocukların resimlerinde ne yapıyor oldukları okul türü açısından farklı sonuçlar ifade etmiştir.

Tablo 6.15. Çocukların resimlerinde ne yapıyor olduklarının cinsiyete göre dağglımları

\begin{tabular}{|c|c|c|}
\hline $\begin{array}{l}\text { Çocukların resimlerinde ne } \\
\text { yapıyor oldukları }\end{array}$ & $\mathrm{K}(f)$ & $\mathrm{E}(f)$ \\
\hline $\begin{array}{l}\text { Çocuklar dişarıda oyun } \\
\text { oynuyorlar }\end{array}$ & 13 & 6 \\
\hline Okula gidiyorlar/geliyorlar & 7 & 3 \\
\hline $\begin{array}{l}\text { Okulun içinde oyuncaklarla } \\
\text { oynuyorlar }\end{array}$ & 2 & 4 \\
\hline Kız spor yapıyor & 1 & - \\
\hline $\begin{array}{l}\text { Teneffüs bitmiş öğrenciler } \\
\text { okula girmiş }\end{array}$ & 1 & - \\
\hline $\begin{array}{l}\text { Okula kim geliyormuş diye } \\
\text { camdan bakıyor }\end{array}$ & - & 1 \\
\hline $\begin{array}{l}\text { Camide ailece namaz } \\
\text { k1lyorlar }\end{array}$ & - & 1 \\
\hline
\end{tabular}

Tablo 6.15. incelendiğinde, hem kızlar ( $f: 13)$ hem de erkekler $(f: 6)$ en çok okulda oyun oynadıklarını ifade etmişlerdir. Sadece kızlar resimlerinde spor yaptıklarını $(f: 1)$, teneffüsün bitip öğrencilerin okula girmiş olduklarını $(f: 1)$ çizmişken; sadece erkekler ise kendisi okula kim geliyormuş diye camdan baktıklarını ( $f: 1)$ ve camide ailece namaz kıldıklarını $(f: 1)$ çizmişlerdir. Bu bulgulara göre, çocukların resimlerinde ne yapıyor oldukları cinsiyete göre benzer sonuçlar ifade etmiştir.

\section{TARTIŞMA VE SONUÇ}

$\mathrm{Bu}$ araştırma okul öncesi eğitim kurumlarındaki 48-71 aylık çocukların okula ilişkin algılarını çizdikleri okul resimleri yoluyla ortaya koymuştur. 48-71 aylık çocukların çoğu okul resimlerinde, en çok okul binasına yer vermiş ve okulu en çok fiziksel özellikleri ile algılamışlardır. Benzer şekilde Yıldız (2012) araştırmasında, ilköğretim öğrencilerinin okul resminde sıklıkla tekrarlanan bir figür olarak okul binası çizdikleri, okulun kavram olarak kuralları ve fiziksel özellikleriyle formal bir yapıda algılandığı, ayrıca katılımcılara ait bireysel farklılıkların resimlerdeki kompozisyona ve kullanılan renklere yansıdığı sonucuna ulaşmıştır. Bu araştırmada en çok okul resmi çizilmesinde çocuklara "Bana bir okul resmi çiz." yönergesinin verilmiş olmasının da etkili olabileceği düşünülebilir.

Araştırmada bazı çocuklar resimlerinde sadece okul binası çizmekle kalmamış, okullarında bulunan ya da bulunmayan iç (sınıf, spor salonu gibi) ve dış mekânları (bahçe, park gibi) çizerek okulu onların temel 
ihtiyaçları olan oyun, spor gibi hareket ihtiyaçlarını karşılayan bir yer olarak algılamışlardır. Bazı çocuklar da okul çevresindeki ev, cami, yol, kreş, dükkân gibi mekânları resmederek okulu çevresiyle bir bütün olarak algılamışlardır. Bazı çocuklar ise resimlerinde okul resmi çizmemiş; ev/kendi evi, kendi köpeğinin kulübesi, çocuk oyun parkı gibi okul olmayan farklı mekanları çizmişlerdir. Bu durum, bazı çocukların okulda bulunmak istememelerinden, evlerinde bulunmayı özlemelerinden ve okul dış1 ortamda kendilerini mutlu hissediyor olmalarından kaynaklanmış olabilir. Yavuzer (2013) okul korkusu olan çocukların okul ve öğrenci çizmeyi istemediklerini belirtmiştir. Araştırmaya benzer şekilde Aksoy ve Baran'ın (2010) 60-72 aylık çocukların resimleri yoluyla okul algılarını incelediği araştırmada, bazı çocukların ( $\mathrm{n}=12)$ okul ortamı dışında kendi evi, arkadaş evi, komşu evi, ırmak ve derenin olduğu yer, çocuk park alanı gibi mutlu oldukları farklı mekanları çizdikleri ortaya koyulmuştur.

Ana sınıfı çocuklarının hiçbirinin okulun dış mekanına park çizmemeleri parkın yokluğuna işaret etmektedir. Gerçekten de araştırmanın yapıldığı 4 ana sınıfının da oyun parkı yoktur. Sadece ana okuluna giden çocuklardan bazılarının oyun parkı ( $f: 5)$ çizdikleri görülmüştür. Halbuki üç anaokulununda oyun parkı vardır. Bu durum, çocukların anaokullarında zamanlarının çoğunluğunu okul içindeki etkinliklerle geçirdiklerini düşündürmektedir. Göl Güven'in (2009) araştırması bu bulguyu desteklemektedir. Araştırmaya göre okul öncesi öğretmenleri hava iyi bile olsa ailelerin istekleri ve kaygıları (soğuk algınlığı ve giysilerin kirlenmesi gibi) doğrultusunda çocukları dışarı çıkarmamakta, açık hava aktivitelerini sınırlı sayıda yaptırmaktadırlar. Benzer şekilde yapılan araştırmalarda okul öncesi çocuklarının okulda neler yaptıklarına ilişkin görüşleri incelendiğinde, zamanlarının büyük çoğunluğunu sınıf içinde oyun oynama ve sanat vb. etkinliklerle geçirdikleri, diğer yandan bahçe oyunlarından ya hiç (Koçyiğit, 2014) ya da çok az bahsettikleri bulunmuştur (Civek ve Çamlıbel Çakmak, 2018). Halbuki Okul Öncesi Eğitim Programında yer alan serbest zaman, Türkçe, oyun/ hareket, müzik, drama, fen/doğa, sanat, okuma yazma çalışmaları ve alan gezisi etkinlikleri hem sınıf içinde hem de açık havada gerçekleştirilebilecek etkinliklerdir. Öğretmenden etkinlikleri sadece sınıfın içinde değil olanaklar dahilinde açık havada da yaptırması beklenmektedir (Milli Eğitim Bakanlığı [MEB], 2013).

Resim, çocukların kişilik özelliklerini yansıtan önemli bir araçtır. Özgüven ve yeterlilik duygusu olan, sosyal ve dışa dönük çocukların resimleri hem kendilerini çizme hem de kağıdın tamamını kullanma, figürler arasında kompozisyonlar oluşturma ve kullandıkları renkler açısından güven duygusu gelişmemiş çocuklara göre farklılıklar gösterebilmektedir (Yavuzer, 2013). Araştırmada okul resimlerinde kendilerini çizen çocukların resimleri ( $f$ : 13), kendilerini okulun parçası hissetmeleri ve okuldaki sosyal ilişkilerinin anlaşılması açısından güzel bir kompozisyon oluşturmaktadır (Bkz. Resim 6.2.). Araştırmaya benzer şekilde Geyik, Çalışkan ve Bay'ın (2019) “Okul Öncesi Dönem Çocuklarının Okul Algılarının Belirlenmesi” adlı çalışmada, çocukların çoğunluğunun olumlu okul algısına sahip olduğu, okul resimlerinde üç ana kriter (okulunu çizme, kendini çizme ve olumlu duygu renklerini kullanma) ile birlikte diğer figürlere (okulunun içinde kendini çizme, arkadaşını çizme, öğretmenini çizme, neşeli figürler) daha çok yer verdikleri belirlenmiştir.

Çocuklar resimlerinde kendisini, ailesi, grup arkadaşları, öğretmeni veya diğer kişilerle birlikte çizdiğinde, resim yoluyla onların gerek kendisiyle olan ilişkisini, gerekse kendisinin grupla ve başkalarıyla olan ilişkisini resimlerine yansıtmış olurlar. Resimler, çocuğun grup içinde kendini nasıl algıladığının ve grup içindeki yerinin belirlenmesi açısından son derece faydalıdır (Yavuzer, 2013). Resmin bir veri toplama aracı olarak tercih edildiği pek çok araştırmada da çocukların çizimler yoluyla aileleri, arkadaşları, öğretmenleri ve sosyal çevreleri olan ilişkilerini çizimler yoluyla kolayca ifade edebildikleri tespit edilmiştir (Aykaç, 2012; Clarke, Ungerer, Chahoud, Johnson ve Steifel, 2002; Fury, Carlson ve Sroufe, 1997; Harrison, Clarke ve Ungerer,2007; Kaplan and Main, 1985; Pianta, Longmaid and Ferguson, 1999 ). Yörükoğlu'na (2011) göre, okul öncesi dönemde çocukların arkadaşlığa verdiği önem artmaktadır. Araştırmada bazı çocuklar okul resimlerinde kendisi dışında sırasıyla en çok çocuk, anne, arkadaş, öğretmen, insane ve kardeş gibi kimseleri çizmişlerdir. Buna göre, çocuklar kendi sosyal ilişkilerini ve okul ortamlarını resimlerine yansıtarak okulu sosyal ilişkilerin kurulup geliştirildiği sosyal bir ortam olarak görmüşlerdir. Benzer şekilde Meslek Lisesi öğrencilerinin okula yönelik algılarının metaforlar yoluyla incelendiği araştırmalarda öğrencilerin büyük bir çoğunluğu birinci sırada okulu otoriter ve disiplinli bir yer, ikinci sırada bilgi veren ve geliştiren bir yer, bir kısım öğrenciler ise arkadaşlık ve dayanışma ortamı olarak algılamışlardır (Bülbül, 2014; Bülbül ve Toker Gökçe, 2015). Araştırmada çocukların resimlerine bakıldığında okulun dış ve iç mekanında oyun oynama (f: 19; f: 6), 
okula gidip gelme (f: 10) vb. eylemlerin yapıldığ 1 , okulda bask1 ve otorite kurma ile ilgili herhangi bir olumsuz figüre ya da eyleme ilişkin bir bulgunun olmadığı görülmektedir. Bu açıdan düşünüldüğünde okul öncesine devam eden çocukların daha üst kadamedeki çocuklara göre okulu daha olumlu algıladığı söylenebilir. Ayrıca çocuklar resimlerinde genellikle kendilerinde duygusal açıdan iz bırakan olay ve kişilere de yer vermektedirler (Yıldız, 2012). Araştırmada bazı çocukların okul resimlerinde masal kahramanları, polis, hırsız ve araştırmacıyı çizmiş olması bu duruma verilebilecek örneklerdendir.

Çocuklar resimlerinde okul ve çevresine ait materyallere $(f: 382)$ doğa öğrelerine (f: 197) göre daha çok yer vermişlerdir. $\mathrm{Bu}$ bulgu, çocukların okul bahçelerinin doğa öğeleri açısından fakir bir görüntüde olduğu izlenimini vermektedir. Gerçekten de çalışma grubuna alınan dört ilköğretim okulunun bahçe zemininin büyük bir bölümü beton yapıdadır ve ağaç, çiçek, çimen, toprak alanlar vb. çok az bulunmaktadır. Çocukların resimlerinde kendi okullarının iç ve dış mekânlarında bulunan ya da bulunmayan doğa öğeleri ile okul ve çevresine ait materyalleri çizdikleri görülmüştür. Norodahl ve Einarsdottir (2014) bir geliştirme projesi kapsamında yaptıkları araştırmada, çocukların çoğunluğunun dışarıda olmaktan hoşlandıklarını, oyun araç-gereçlerinde çeşitliliği sevdiklerini (sulu kaydıraklar gibi), doğal ortamların onlara çeşitli oyun firsatları sağladığını (ağaç ve tepe üstlerine yuva yapmak, su oyunları, çiçek toplamak gibi), bu bakımdan doğal çevreye değer verdiklerini tespit etmişlerdir.

$\mathrm{Bu}$ araştırmada ana sınıflarına giden çocuklar resimlerinde doğa öğeleri ve okul ve çevresine ait materyallere anaokullarına giden çocuklardan daha çok yer vererek ana sınıflarının iç ve dış mekânlardaki materyal yönünden eksikliğini, özellikle de çocukların ana sınıflarına ait bir bahçeye olan özlemlerini dile getirmişlerdir. Bakıldığında çalışma grubununa alınan üç bağımsız anaokulunun oyun araç gereçleri ve çimen, çiçek, ağaç, toprak gibi alanları olan kendine ait bahçesi varken, dört ana sınıfınında kendine ait böyle bir bahçesi yoktur. Anaokuluna giden çocukların ise kendi okullarına ait düzenlenmiş ve doğa öğeleri açısından daha zengin bir okul bahçeleri olmasına rağmen, resimlerinde okul ve çevresindeki materyallere $(f: 187)$ göre doğa öğelerine $(f: 89)$ daha az sayıda yer verdikleri bulunmuştur. $\mathrm{Bu}$ bulgu, onların dış mekandan yeterince yaralanamadıklarını ve genellikle okul iç mekanında yapılan etkinliklerle vakit geçirdiklerini düşündürmektedir. Anaokullarındaki bazı çocukların (f: 6) resimlerinde kendilerini okulun içinde oyun oynarken çizmeleri bu bulguyu destekler niteliktedir. Okul öncesi eğitim kurumları planlanırken, çocukların serbestçe hareket etme, oyun oynama gibi temel ihtiyaçları dikkate alınmalı (Oktay, 2000), ilgi çekici ve uyaran yönünden zengin çevre nitelikleri ile donatılmış olmalıdır (Tok 2015). Çünkü iyi düzenlenmiş mekanlar çocuklar için ilgi çekici olmakta ve fiziksel mekana olan olumlu duygularını okullarına, öğretmenlerine ve arkadaşlarına yansıtabilmektedirler (Kildan, 2007). Dış mekanın düzenli ve aktif bir şekilde kullanımının özendirilmesi konusunda başta Milli Eğitim Bakanlığı olmak üzere okul öncesi öğretmenlerine önemli görevler düştüğü de açıktır. Sonuç olarak her iki okul türünden de bazı çocuklar okulu, onlara arkadaşlarıyla oyun oynama, serbestçe hareket etme gibi temel ihtiyaçlarını karşılayan, onlara öğrenme firsatları sağlayan doğal ortamı olan, oyun araç gereçleri ile dopdolu bir yer olarak resimlerine yansıtnışlardır.

Hem kızlar (f: 201, $f: 130)$ hem de erkekler ( $f: 179, f: 67)$ resimlerinde okula ve çevresine ait materyalleri doğa öğelerinden daha çok çizmişlerdir. Bu duruma "Bana bir okul resmi çiz" yönergesi sebep olmuş olabilir. Ayrıca kızlar erkeklere göre daha çok doğa öğeleri ile okul ve çevresine ait materyalleri çizmişlerdir. Bu durum, kızların erkeklere göre daha fazla güzellik, estetik ve ayrıntılara önem veren doğal yapılarının sonucu olabilir. Bu bulguyu geçmişte yapılan çalışmalar da desteklemektedir. Brown (1990), 5-11 yaşları arasındaki çocuklara, Cox, Perara, Kayosu veHiranuma (2001) 7-11 yaşları arasındaki çocuklara bir insan resmi çizdirmişler. Adı geçen çalışmalarda çocuklardan yaşı büyük olanlarla, kızların küçük olanlara ve erkeklere göre insan resimlerinde daha fazla ayrıntıya yer verdikleri bulunmuştur (Akt. Kindap ve Sayıl, 2005). Yine benzer şekilde Hall (2008) 56-71 aylık çocukların çizimleri aracılığıyla iletişim becerilerini incelediği araştırmasında kızların erkeklerden daha fazla estetik kaygılar yaşadıklarını, çizimlerinde daha fazla süslemelere (stiker,renkler vb.) ve ayrıntılara (kalp,çiçek, yazı vb.) yer verdiklerini belirtmiştir. 4-7 yaş çocuklarının gelişim özelliklerinin incelendiği bir diğer araştırmada ise $126 \mathrm{kız}$ ve 144 erkek çocuğuna "Okulum ve ben" konulu bir resim çizdirilmiştir. Resimlerde kızların erkeklere göre (kızlar \%80,2, erkekler \%64,6) daha ayrıntılı nesneler çizdikleri (bir eve kapı, pencere gibi ekler) ve yine kızların erkeklerden (kızlar: \%61,9, erkekler: \%38,2) daha fazla dekoratif süslemeler yaptıkları tespit edilmiştir (Aral ve Metin, 2012). 
Çocukların resimlerinde ne yapıyor olduklarına bakıldığında, çalışma grubuna alınan 117 çocuktan sadece 19'unun çocukları dışarıda oyun oynarken çizdikleri görülmektedir. Bazı çocuklar resimlerinde en çok çocukları ya da arkadaşlarını dışarıda araçlı araçsız oyuncaklarla ya da bahçe oyuncaklarıyla oyun oynarken çizerek harekete ve okul dış mekanına (bahçeye) verdikleri önemi ifade etmişlerdir. Einarsdottir (2005) yaptığı araştırmada okul öncesi çocukların çoğunluğunun öğretmenden gelen yönergeleri takip etmekte zorlandıklarını, etkinlik seçimi yapamamaktan, sınıf içinde sessiz ve hareketsiz kalmalarını gerektiren etkinlikleri yapmaktan hoşlanmadıklarını tespit etmiş̧ir. Ayrıca çocuklar diğer çocuklarla birlikte olmayı, iyi ilişkiler kurmayı ve açı hava alanlarında oyun oynamayı önemli görmüşlerdir (Clark ve Moss, 2005; Einarsdottir, 2005). Benzer şekilde Aksoy ve Baran (2010) "60-72 Aylık Çocukların Okula İlişkin Algılarının İncelenmesi" adlı araştırmalarında çocukların resimlerinde mutlu oldukları mekanları incelemişler ve çocukların \%23,3'ünün $(n=14)$ resimlerinde bahçe alanına yer vermiştir. Diğer yandan araştırmamızda anasınıfına giden bazı çocukların $(f: 15)$ anaokullarına giden bazı çocuklara $(f: 4)$, göre resimlerinde daha çok çocuklarla dışarıda oynama ve çocukların okula gidip gelme eylemini çizdikleri, ancak çocukları okulun içinde oyun oynarken hiç çizmedikleri görülmüştür. $\mathrm{Bu}$ durum, ana sınıfına giden çocukların okul dış mekanında oynanan oyun ve harekete olan ihtiyaçlarını, özellikle de oyun-araç gereçlerinin olduğu parka olan özlemlerini ifade etmiştir. Buna göre, bazı çocuklar okulu açık havada oyun ve hareket ihtiyaçlarının karşılandığı bir yer olarak algılamışlardır.

Araştırma sonucunda, okul resimlerinde çocuğun devam ettiği okul türüne göre; çizdiği mekânın, kendini çizip çizmeme durumunun, kendisi dışında bir kimse ya da canlı/cansız varlık çizme durumunun, doğa öğeleri ve materyallere yer verme durumunun benzer sonuçlar ifade ettiği; ancak okulun bahçesinin bulunma ya da bulunmama durumuna göre ne yapıyor olduğunun farklı sonuçlar ifade ettiği ortaya konmuştur. Çocuğun cinsiyetine göre ise çizdiği mekânın, kendini çizip çizmeme durumunun, ne yapıyor olduğunun benzer sonuçlar ifade ettiği, ancak kendisi dışında bir kimse ya da canlı/cansız çizme durumunun, okulun iç ve dış mekânlarında bulunma ya da bulunmama durumuna göre doğa öğelerine ve materyallere yer verme durumunun farklı sonuçlar ifade ettiği bulunmuştur. Buna göre, çocuğun okula ilişkin algılarında okul öncesi eğitim kurumlarının mekân nitelik ve niceliğinin etkili olduğu, kurumların iç ve dış mekân düzenlemelerine gereken önemin verilmesi gerektiği söylenebilir. Özellikle okul öncesi kurumlarının dış mekânlarının aktif şekilde, sıklıkla kullanımını özendirecek aile katılım çalışmalarına eğitim programları içinde yer verilebilir, bu konuda kapsamlı eğitimler verilerek aileler bilinçlendirilebilir.

Araştırmada çocuklara resim çizdirip anlattırma veri toplama tekniği kullanılmıştır. Başka araştırmalarda görüşme, gözlem, fotoğraf, okul resimlerinin (iç ve dış mekân) gösterildiği, okullara geziler yapılarak çocukların ufkunun genişletildiği vb. farklı veri toplama tekniklerinin kullanıldığı nitel ya da nicel çalışmalar yapılabilir. İlköğretim okullarının bünyesinde yer alan ana sınıflarının okul bünyesinden ayrılması sağlanarak, kendilerine ait bir bina ve bahçede eğitim-öğretim çalışmalarına devam edebilmeleri yönünde girişimlerde bulunabilir. $\mathrm{Bu}$ araştırma okul algısını çocuk bakış açısından ele almıştır. Bundan sonra yapılacak araştırmalarda okul öncesi öğretmeni, çocuk ve ebeveynlerin okul algılarının ya da okulun öğelerinden sınıf, bahçe vb. farklı algıların belirlenmesi amaçlanabilir.

Bilgilendirme / Acknowledgement: Bu çalışma İlknur CiVEK tarafindan Dr. Öğr. Üyesi Özlem ÇAMLIBEL ÇAKMAK danışmanlığında 2018 yılında hazırlanan "Okul Öncesi Eğitim Kurumlarına Devam Eden 48-71 Aylık Çocukların Okul Algılarının İncelenmesi” adlı yüksek lisans tez çalışmasından üretilmiştir.

\section{KAYNAKÇA}

Açıkalın, A., Şişman, M. ve Turan, S. (2007). Bir insan olarak okul müdürü. Ankara: Pegem A Yayıncilik.

Akkaya, E. (2012). Ortaöğretim öğrenci ve öğretmenlerinin okul ve ideal okul algilarının metaforlar yoluyla analizi. Yayımlanmamış yüksek lisans tezi, Gazi Üniversitesi, Eğitim Bilimleri Enstitüsü, Eğitim Yönetimi ve Denetimi Bilim Dalı, Ankara. 
Aksoy, P. ve Baran, G. (2010). 60-72 aylık çocukların okula ilişkin algılarının resimler yoluyla incelenmesi. International Conference on New Trends in Education in Their Implications, Antalya-Türkiye.

Aptekar, L. (1981). Sociological and psychological factors of Mexican American high school students' perception of school. Education, 102(1), 16-26.

Aydoğdu, E. (2008). Illköğretim okullarındaki öğrenci ve öğretmenlerin sahip oldukları okul algıları ile ideal okul algılarının metaforlar (mecazlar) yardımıyla analizi. Yayımlanmamış yüksek lisans tezi, Eskişehir Osmangazi Üniversitesi, Fen Bilimleri Enstitüsü, Eskişehir.

Aykaç, N. (2012). İlköğretim öğrencilerinin resimlerinde öğretmen ve öğrenme süreci algısı. Ĕgitim ve Bilim, 37(164), 298-315.

Bilgiç, S. ve Sarı, M. (2010). İlköğretim öğrencilerinin okul yaşam kalitesi ve empatik sınıf atmosferi algıları. Eğitim Bilimleri ve Uygulama, 9(17), 1-19.

Bülbül, T. (2014). Meslek lisesi öğrencilerinin okullarına ve mesleki eğitime yönelik görüşleri. Yayımlanmamış yüksek lisans tezi, Kocaeli Üniversitesi; Sosyal Bilimler Enstitüsü, Eğitim Yönetimi, Teftişi, Planlaması Ve Ekonomisi Bilim Dalı, Kocaeli.

Bülbül, T. ve Toker Gökçe, A. (2015). Meslek lisesi öğrencilerinin metaforik okul algısı: İşlevselci bir yaklaşım. Kırşehir Eğitim Fakültesi Dergisi, 16(2), 273-291.

Cerit, Y. (2006). Öğrenci, öğretmen ve yöneticilerin okul kavramıyla ilgili metaforlara ilişkin görüşleri. Kuram ve Uygulamada Eğitim Bilimleri, 6(3), 669-699.

Civek, İ. ve Çamlıbel Çakmak, (2018). Okul Öncesi Eğitim kurumlarına devam eden 48-71 aylık çocukların görüşlerine göre okul algılarının incelenmesi. Journal of Social and Humanities Sciences Research, 5(26), 2571-2593.

Clark, A. ve Moss, P. (2005). Space to Play. More Listening to Young Children Using the Mosaic Approach. London: National Children's Bureau. 5 Temmuz 2019 tarihinde https://books.google.com.tr/books/ adresinden erişildi.

Clarke, L., Ungerer, J., Chahoud, K., Johnson, S. ve Steifel, I., (2002). Attention deficit disorder isassociated with attachment insecurity. Clinical Child Psychology and Psychiatry (7), 179-198.

Çalık, E. (2008). Illköğretim öğrencilerinin iyimserlik düzeylerinin ve okula ilişkin algılarının incelenmesi. Yayımlanmamış yüksek lisans tezi, Ankara Üniversitesi; Eğitim Bilimleri Enstitüsü, Eğitimde Psikolojik Hizmetler Bilim Dalı, Ankara.

Demirel, Ö. (2010). Ĕ̌itim sözlüğ̈̈/Dictionary of education: Türkçe-Ingilizce/İngilizce-Türkçe (Geliştirilmiş 4. Baskı). Ankara: Pegem Akademi.

Döş, İ. (2011). Okul paydaşlarının metaforlar yardımıyla okul örgütlerini algılama biçimlerinin değerlendirilmesi. Yayımlanmamış doktora tezi, Fırat Üniversitesi, Sosyal Bilimler Enstitüsü, Elazı̆g.

Einardottir, J. (2005). We can decide what to play! children's perception of quality in an Icelandic playschool. Early Education and Development, 16(4), 469-488.

Erden, M. (1998). Öğretmenlik mesleğine giriş. İstanbul: Alkım Yayınları.

Fury, G., Carlson, E. A. ve Sroufe, L. A. (1997) Children's representations of attachment relationships in family drawings. Child Development, 68(6), 1154-1164.

Geyik, Ş., Çalışkan, Y. M. ve Bay, D. N. (2019). Okul Öncesi dönem çocuklarının okul algılarının belirlenmesi. Ihlara Eğitim Araştırmaları Dergisi, 4(1), 1-17.

Göl Güven, M. (2009). Evaluation of the qualty of early childhood classrooms in Turkey. Early Childhood Development and Care, 179(4), 437-451.

Hall, E. (2008, September). 'My brain printed it out!'” Drawing, communication, and young children: a 
discussion. British Educational Research Association Annual Konferansinda sunulan bildiri, Heriot-Watt University, Edinburgh, 12 Temmuz 2019 tarihinde https://s3.amazonaws.com/academia.edu.documents/36844871/174158.pdf?responsecontent-disposition adresinden erişildi.

Harrison, L.J., Clarke, L. ve Ungerer, J. A. (2007) Children's drawings provide a new perspective on teacher-child relationship quality and school adjustment. Early Childhood Research Quarterly (22), 55-71.

Hofman, R. H., Adrian Hofman, W. H. ve Guldemond, H. (2001). Social context effects on pupils' perception of school. Learning and Instruction, 11(3), 171-194.

Inbar, DE. (1996). The free educational prison: metaphors and images. Educational Research, 38(1), $77-$ 92. ERIC No: EJ521111

Kaplan, N. and Main, M. (1985, April). Internal representations of attachment at six years as indicated by family drawings and verbal responses to imagined separations. In M. Main (Chair), Attachment: A Move to the Level of Rrepresentation. Symposium Conducted at the Meeting of the Society for Research in Child Development, Toronto, Canada.

Kıldan, A. O. (2007). Okul öncesi eğitim ortamları. Kastamonu Eğitim Dergisi, 15(2), 501-510.

Kındap, Y. ve Sayıl, M. (2005). Çocuk çizimlerinde temsil ve ifade: Doğrusal ve doğrusal olmayan gelişim. Türk Psikoloji Dergisi, 20(56), 25-39.

Koçak, C. (2013). Metaphorical perceptions of teacher candidates towards the school concept: Lotus flower model. Mevlana International Journal of Education, 3(4), 43-56.

Koçyiğit, S. (2014). Çocukların bakış açısıyla okul öncesi eğitim. Pamukkale Üniversitesi Eğitim Fakültesi Dergisi, 36, 203-214.

Levine, P. M. (2005). Metaphors and images of classrooms. Kappa Delta Pi Record, 41(4), 172-175.

Mahlios, M. ve Maxson, M. (1998). Metaphors as sturucters for elementary and secondary preservice teachers' thinking. International Journal of Educational Research, 29, 227-240.

Merriam, S.B. (2009). Nitel araştırma desen ve uygulama için bir rehber. (Turan, S. (çev. ed.). Ankara: Nobel Akademik Yayıncılı.

Metin, Ş. ve Aral, N. (2012). Dört-yedi yaş çocuklarının resim gelişimsel özelliklerinin incelenmesi. Ankara Sağllk Bilimleri Dergisi, 1(2), 55-69.

Okul öncesi eğitim programı (2013). Ankara: Milli Eğitim Bakanlı̆̆ Temel Eğitim Genel Müdürlüğü.

Nalçacı, A ve Bektaş, F. (2012). Öğretmen adaylarının okul kavramına ilişkin algıları. Ahi Evran Üniversitesi, Kırşehir Ĕgitim Fakültesi Dergisi, 13(1), 239-258.

Norðdahl, K ve Einarsdóttir, J. (2014). Children's views and preferences regarding their outdoor environment. Journal of Adventure Education and Outdoor Learning, 15(2), 152-167.

Oktay, A. (2000). Yaşamın sihirli yıllarl: Okul öncesi dönem. (2. Bask1). İstanbul: Epsilon Yayınc1lık.

Özdemir, M. ve Kalaycı, H. (2013). Okul bağlılı̆gı ve metaforik okul algısı üzerine bir inceleme: Çankırı ili örneği. Kuram ve Uygulamada Eğitim Bilimleri, 13(4), 2125-2137.

Pianta, R. C. (1994). Patterns of relationships between children and kindergarten teachers. Journal of School Psychology, 32, 15-31.

Poyraz, H. (2003). Okulöncesinin önemi. (Poyraz, H. ve Dere, H. Ed.). Okul Öncesi Eğitimin İlke ve Yöntemleri (2. Baskı. s. 17- 22) içinde. Ankara: Anı Yayıncıl1k.

Ryan-Wenger, N. (2001). Use of children's drawings for measurement of developmental level an emotional status. Journal of Child and Family Nursing, 4, 139-149.

Saban, A. (2008). Okula ilişkin metaforlar. Kuram ve Uygulamada Eğitim Yönetimi, 55, 459-496. 
Sağlam, A. Ç. (2010). Okul örgütü ve yönetimi. (Memduhoğlu, H. B. ve Yılmaz, K. Ed). Türk Eğitim Sistemi ve Okul Yönetimi (Geliştirilmiş 2. Bask1., s. 171-202) içinde. Ankara: Pegem A Akademi.

Skypo, T., Ryan-Wengwe, N. ve Su, Y. (2007). Human figure drawings as a measure of children's emotional status: Critical review for practice. Journal of Pediatric Nursing, 22(1), 15-28.

Taştan, N. (2013). Examination of high school students' metaphoric school perceptions in terms of various variables: Some evidence from Turkey. Educational Research and Reviews, 8(20), 1948 1954.

Tok, E. (2015). Okul öncesi eğitimde eğitim ortamları. (G. Uyanık Balat, Ed.). Okul öncesi eğitime giriş. (Geliştirilmiş. 5. Baskı., s. 162-177) içinde. Ankara: Nobel Yayıncılık.

Türkmen, A. (2014). Öğrenci algılarına göre mutlu okulun incelenmesi. Yayımlanmamış yüksek lisans tezi, Zirve Üniversitesi, Sosyal Bilimler Enstitüsü, Gaziantep.

Wesson, M. and Salmon, K (2001). Drawing and showing: Helping children to report emotionally laden events. Applied Cognitive Psychology, 15, 301-320.

Wood, D. (2003). Çocuklarda düşünme ve ögrenme. (Özünlü, M. Çev.). Ankara: Doruk Yayımcılık.

Yavuzer, H. (2013). Resimleriyle Çocuk (17. Bask1.). İstanbul: Remzi Kitabevi.

Yıldırım, H. ve Yıldırım, A. (2013). Sosyal bilimlerde araştırma yöntemleri (9. Bask1.). Ankara: Seçkin Yayıncilik.

Yıldız, A. (2012). Ilkögretim birinci kademe öğrencilerinde "okul" kavramına ilişkin nitel bir analiz. Kuram ve Uygulamada Ĕgitim Bilimleri, 12 (2), 609-626.

Yörükoğlu, A. (2011). Çocuk ruh sağlı̆̆ı. (31. Baskı.). İstanbul: Özgür Yayınları.

Zieman, G. L. ve Benson, G. P. (1981). School perception of truant adolescent girls. Behavioral Disorders, 6(4), 197-205. 